\title{
Assessment of beetle diversity, community composition and potential threats to forestry using kairomone-baited traps
}

\author{
S. Olivier-Espejel*, B.P. Hurley and J. Garnas \\ Department of Zoology and Entomology, Forestry and Agricultural Biotechnology Institute (FABI), University of \\ Pretoria, 0002, South Africa
}

\author{
*Address for correspondence \\ Phone: +1 6038622094 \\ Fax: +1 6038624976 \\ E-mail: \\ Sarai.Olivier@fabi.up.ac.za
}

\begin{abstract}
Traps designed to capture insects during normal movement/dispersal, or via attraction to non-specific (plant) volatile lures, yield by-catch that carries valuable information about patterns of community diversity and composition. In order to identify potential native/introduced pests and detect predictors of colonization of non-native pines, we examined beetle assemblages captured in intercept panel traps baited with kairomone lures used during a national monitoring of the woodwasp, Sirex noctilio, in Southern Africa. We identified 50 families and 436 morphospecies of beetles from nine sites sampled in both 2008 and 2009 and six areas in 2007 (trap catch pooled by region) across a latitudinal and elevational gradient. The most diverse groups were mainly those strongly associated with trees, known to include damaging pests. While native species dominated the samples in terms of richness, the dominant species was the introduced bark beetle Orthotomicus erosus (Curculionidae: Scolytinae) ( $22 \pm 34$ individuals/site). Four Scolytinae species without previous records in South Africa, namely Coccotrypes niger, Hypocryphalus robustus (formerly Hypocryphalus mangiferae), Hypothenemus birmanus and Xyleborus perforans, were captured in low abundances. Communities showed temporal stability within sites and strong biogeographic patterns across the landscape. The strongest single predictors of community composition were potential evaporation, latitude and maximum relative humidity, while the strongest multifactor model contained elevation, potential evaporation and maximum relative humidity. Temperature, land use variables and distance to natural areas did not significantly correlate with community composition. Non-phytophagous beetles were also captured and were highly diverse (32 families) perhaps representing important beneficial insects.
\end{abstract}

\section{Introduction}

Insect and disease monitoring forms the cornerstone of an integrated pest management (IPM) approach to limiting biotic damage in forestry and agriculture and is critical for managing natural ecosystems worldwide. Despite growing recognition that community composition and biodiversity within managed ecosystems can have important consequences for productivity, nutrient cycling, pollination, natural pest control and 
damage severity by native or exotic pests (Vandermeer et al., 1998; Jactel et al., 2005; Vergara \& Badano, 2009), monitoring typically focuses on one or a few pest species (Aukema et al., 2010; Crook et al., 2014). Incomplete knowledge of non-pest species that form part of local assemblages and that have the potential to interact with known pests can limit understanding of the role of community in driving system dynamics. Further, lack of complete knowledge of the native or exotic herbivores present in managed ecosystems with the potential to cause damage or interact with crop-associated communities, can influence preparedness for future pest outbreaks and reduce accuracy in economic or ecological risk assessment modeling.

One approach to partially addressing gaps in knowledge of the biodiversity and community composition within managed landscapes is to leverage existing monitoring efforts targeting pest species. While the use of highly specific monitoring methods such as synthetic pheromone-baited traps are typically preferred for their greater efficiency and limited nontarget effects, no such technologies are available for the majority of insect pests. Monitoring efforts using non-specific (e.g., flight intercept, sticky traps, pitfall traps, etc.), semi-specific methods (i.e., traps baited with generalized attractants such as plant stress volatile blends) and even specific pheromonal blends tend to yield significant insect by-catch (Thomas, 2003; Buchholz et al., 2011; Etxebeste et al., 2013; Martin et al., 2013). Incidental trap capture is often discarded without further scrutiny despite significant information that such samples have for understanding associated community context and patterns of biodiversity. Importantly, these samples also represent a key tool for the detection of newly introduced and/or potentially problematic species (i.e., those attaining pest status elsewhere, or belonging to groups that have; Stone et al., 2010; Skvarla \& Holland, 2011; DiGirolomo \& Dodds, 2014). The study of insect by-catch can likewise help establish the distribution and relative abundance of potentially beneficial species such as pollinators, predators and parasitoids, including introduced biological agents (Hatten et al., 2013; Spears \& Ramirez, 2015). Certain species or guilds may also serve as bioindicators of habitat quality or ecosystem integrity (Maleque et al., 2009). Where trapping has taken place over multiple years and/or large geographic areas, samples can be examined with respect to climate and landscape variables that vary spatiotemporally, thus allowing for a more systematic assessment of patterns of species diversity and community composition across ecological or landscape-scale gradients (Hatten et al., 2013; Spears \& Ramirez, 2015). Finally, insect bycatch also provides crucial baseline data that can be preserved for future examination of community perturbations linked to species invasion, land use or climate change (BabinFenske et al., 2008; Buchholz et al., 2011).

In this study we examined beetle by-catch from a multi-year, geographically extensive trapping effort aimed at mapping the current range of the invasive European woodwasp, Sirex noctilio Fabricius (Hymenoptera: Siricidae), in pine plantations in southern Africa. $S$. noctilio was detected in the Western Cape of South Africa in 1994 (Tribe, 1995) and is spreading rapidly through southern Africa. In many cases it might be relevant to examine by-catch data from the perspective of changes to community as a function of focal species presence/absence or abundance. However, data emerging from early detection programs (such the current study) where traps are deliberately placed in advance of an infestation can be challenging to interpret in this way due to an over-representation of traps that yield zero or a few focal species individuals. At the time of sampling used in this study (2007-2009) S. 
noctilio populations had reached pine plantations in Swaziland and the Mpumalanga province of South Africa (Hurley et al., 2012), but was absent from most traps and where it was present, abundance was rarely greater than a few individuals.

The $S$. noctilio trap by-catch resource represents a spatially replicated assessment of the subset of beetles that are attracted to the plant stress lures, which we identified to family, often to genus and either further to species or grouped into morphospecies. Samples were analyzed to assess landscape-scale patterns of biodiversity and community composition as well as to improve understanding the distribution of insects of potential importance to the plantation pine resource in southern Africa. Our goals were fourfold, namely to: (1) inspect all samples for previously undetected nonnative species that could impact forest plantations and native ecosystems; (2) survey the distribution and relative dominance of known invaders relative to native species across major pine-growing regions of South Africa; (3) examine temporal fidelity and spatial turnover of beetle assemblages within and among sites; and (4) evaluate the relative contribution of local, regional and landscape-scale predictors to beetle diversity and composition.

\section{Materials and methods}

\section{Background - S. noctilio in South Africa}

The European woodwasp, S. noctilio is native to northern Africa and has become one of the most harmful pests in exotic pine forest plantations in the Southern Hemisphere (Hurley et al., 2007). More recently, it has also been found, infesting pines in North America and it continues to spread to new areas (Ryan et al., 2012; Slippers et al., 2015). From 2007 to 2010 a network of traps was deployed across $6^{\circ}$ of latitude in an effort to monitor for new outbreaks of $S$. noctilio along the advancing front of the infestation in the South African landscape (Hurley et al., 2012). We analyzed the beetle by-catch from three years (2007, 2008 and 2009) during which the spread of $S$. noctilio was actively monitored through the major pine growing areas of the eastern and northern provinces of the country (principally KwaZulu-Natal, Mpumalanga and Limpopo; Lantschner et al., 2014) and Swaziland. The wasp was not yet established in the sites used for this study when sampling occurred, and it was only occasionally captured in the traps.

\section{Study sites and collection method}

Panel traps baited with a synthetic kairomone lure (designed to mimic pine stress volatiles), were set up in November-December of 2007-2009, during the flight season of S. noctilio. The traps were placed inside or nearby Pinus patula Schiede and Pinus elliottii Engelm plantations. Lures were supplied by Insect Science (Pty) Ltd (Tzaneen, South Africa) and comprised a blend of (+)- $\alpha$-pinene (12.5\%), (-)- $\alpha$-pinene (12.5\%), (-)- $\beta$-pinene $(25.0 \%),(+)-3-$ carene $(30.0 \%),(+)$-camphene $(5.0 \%), \beta$-myrcene $(10.0 \%),(+)$-limonene $(2.5 \%)$ and $(-)$ limonene (2.5\%)). Insects were caught in collection cups filled every week with soapy water. Three traps per site were selectively placed along the leading edge of the $S$. noctilio infestation in South Africa and Swaziland (Hurley et al., 2012; Lantschner et al., 2014). Sampling sites from 2008, replicated in 2009, included the Hhohho Region, in Swaziland (one site) and two South African provinces: Mpumalanga (five sites) and Limpopo (three 


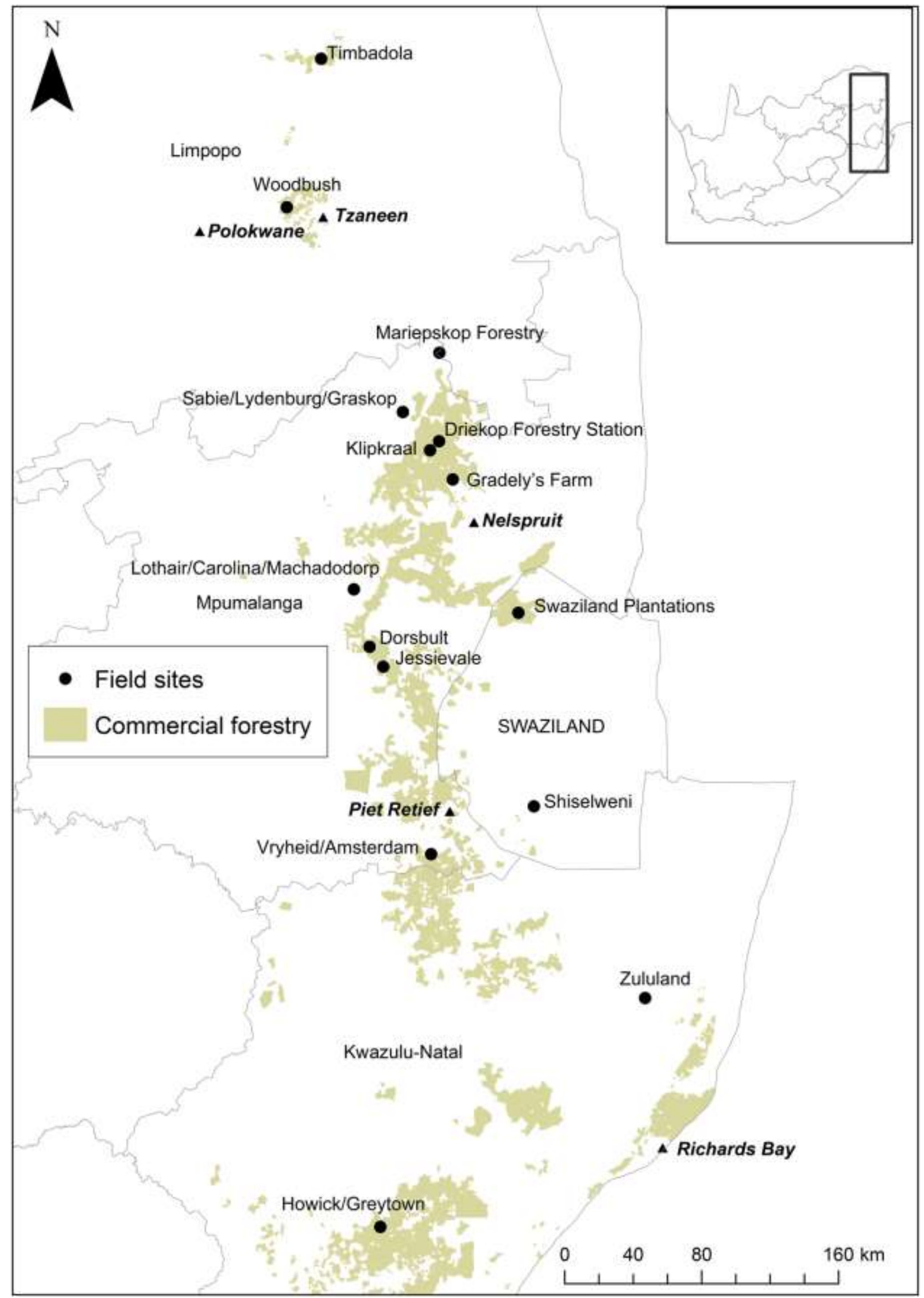

Fig. 1. Map of the study sites and sampling areas 2007- 2009 and plantation areas surrounding each site. 
sites) (fig. 1, table 1). Samples from 2007 included traps from KwaZulu-Natal (KZN) (two areas) and Mpumalanga (three areas) provinces in South Africa and the Shiselweni Region in Swaziland (one area). The 2007 sampling locations are referred to as 'areas' as trap capture from 2 to 3 sites were previously pooled, confounding analyses of community correlation with environment and landscape predictors. Pooled locations encompassed the southernmost sites in KZN and carry important information of overall biodiversity together with the potential to detect unreported invaders species. Given that monitoring was motivated by the goal of tracking woodwasp spread (Hurley et al., 2012), sites were abandoned once wasp populations had established, limiting temporal replication in several sampling sites and areas (Gradely's Farm, Mpumalanga and all areas from 2007).

Table 1. Sampling site characteristics and collection years.

\begin{tabular}{|c|c|c|c|c|c|}
\hline $\operatorname{Farm}(s)$ & Province & Location & & Elevation (m) & Year(s) \\
\hline Timbadola & Limpopo & $23^{\circ} 01^{\prime} 23^{\prime \prime} \mathrm{S}$ & $30^{\circ} 11^{\prime} 39^{\prime} \mathrm{E}$ & 819.6 & 2008 and 2009 \\
\hline Woodbush & Limpopo & $23^{\circ} 48^{\prime} 09^{\prime \prime} \mathrm{S}$ & $29^{\circ} 58^{\prime} 50^{\prime} \mathrm{E}$ & 1625.3 & 2008 and 2009 \\
\hline Mariepskop Forestry & Limpopo & $24^{\circ} 35^{\prime} 03^{\prime \prime} \mathrm{S}$ & $30^{\circ} 50^{\prime} 35^{\prime \prime} \mathrm{E}$ & 1152.6 & 2008 and 2009 \\
\hline Driekop Forestry Station & Mpumalanga & $24^{\circ} 54^{\prime} 13^{\prime \prime S}$ & $30^{\circ} 48^{\prime} 34^{\prime \prime} \mathrm{E}$ & 1491 & 2008 and 2009 \\
\hline Klipkraal & Mpumalanga & $25^{\circ} 03^{\prime} 04^{\prime \prime} \mathrm{S}$ & $30^{\circ} 49^{\prime} 55^{\prime} \mathrm{E}$ & 1342 & 2008 and 2009 \\
\hline Gradely's Farm & Mpumalanga & $25^{\circ} 15^{\prime} 10^{\prime \prime} \mathrm{S}$ & $30^{\circ} 54^{\prime} 28^{\prime} \mathrm{E}$ & 949.1 & 2009 \\
\hline Swaziland Plantations LTD & Hhohho Region & $25^{\circ} 57^{\prime} 42^{\prime \prime} \mathrm{S}$ & $31^{\circ} 16^{\prime} 43^{\prime \prime} \mathrm{E}$ & 964.8 & 2008 and 2009 \\
\hline Jessievale & Mpumalanga & $26^{\circ} 14^{\prime} 02^{*} S$ & $30^{\circ} 29^{\prime} 03^{\prime} \mathrm{E}$ & 1776.8 & 2008 and 2009 \\
\hline Sabie/Lydenburg/Graskop ${ }^{1}$ & Mpumalanga & $24^{\circ} 53^{\prime} 37^{\prime \prime} \mathrm{S}$ & $30^{\circ} 37^{\prime} 31^{\prime \prime} \mathrm{E}$ & 1306 & 2007 \\
\hline Zululand $^{1}$ & $\mathrm{KZN}$ & $28^{\circ} 36^{\prime} 0^{\circ} \mathrm{S}$ & $32^{\circ} 5^{\prime} 0^{\circ} \mathrm{E}$ & 100 & 2007 \\
\hline Shiselweni, Swaziland ${ }^{1}$ & Shiselweni Region & $26^{\circ} 58^{\prime} 57^{*} \mathrm{~S}$ & $31^{\circ} 21^{\prime} 15^{\prime \prime} \mathrm{E}$ & 966 & 2007 \\
\hline Howick/Greytown ${ }^{1}$ & $\mathrm{KZN}$ & $29^{\circ} 11^{\prime} 02^{\prime S} \mathrm{~S}$ & $30^{\circ} 23^{\prime} 53^{\prime \prime} \mathrm{E}$ & 1063 & 2007 \\
\hline Lothair/Carolina/Machadodorp ${ }^{1}$ & $\mathrm{KZN}$ & $25^{\circ} 49^{\prime} 23^{\prime} \mathrm{S}$ & $30^{\circ} 19^{\prime} 18^{\prime \prime} \mathrm{E}$ & 1591 & 2007 \\
\hline Vryheid/Amsterdam ${ }^{1}$ & Mpumalanga/KZN & $27^{\circ} 13^{\prime} 33^{\prime \prime} \mathrm{S}$ & $30^{\circ} 44^{\prime} 41^{\prime \prime} \mathrm{E}$ & 1203 & 2007 \\
\hline
\end{tabular}

${ }^{1}$ locations and elevations are an average of the pooled sites.

\section{Sample preparation and identification}

Beetle specimens collected from traps were stored in $70 \%$ ethanol and later dry mounted and sorted to morphospecies based on external characters and general appearance. All insects were identified to order and family after Scholtz and Holm, 2012. Wherever possible, sorted specimens were further identified to genus and/or species using available insect reference collections at the Ditsong National Museum of Natural History and the South African National Collection of insects in Pretoria. The Family Staphylinidae was omitted from our analyses as resources for identification were limited and morphological differences were minimal. Voucher specimens were deposited at the Forestry and Agricultural Biotechnology Institute (FABI), University of Pretoria, South Africa. Special attention in identification was given to specimens from families known to contain members that can use pine and other trees as hosts, namely Cerambycidae, Chrysomelidae, Scarabaeidae, with particular emphasis on the white grubs (subfamily Melolonthinae), and Curculionidae, with focus on the bark and ambrosia beetles (subfamily Scolytinae).

\section{Data analysis}

Individual-based rarefaction and extrapolation curves were calculated in R 2.3.1 (R Core Team, 2015) using the iNEXT package (Gotelli and Colwell, 2011; Chao et al., 2014; Hsieh et 
al., 2014). Rarefaction allows for the unbiased comparison of species richness across sampling sites and years irrespective of number of individuals collected. Shannon and Inverse Simpson indices were calculated for each site and both years. Beetle composition of sites were visualized and statistically examined for each sampling year and sites using nonmetric multidimensional scaling (NMDS) and a permutational multivariate analysis of variance (PERMANOVA) using Bray-Curtis distance in the vegan package of $\mathrm{R}$ (Oksanen et al., 2015). Data were square-root transformed to reduce the influence of abundant taxa. The same procedure was followed for each year independently and then for both sampling years combined.

\section{Local and regional predictors of diversity and composition}

In order to identify the possible influence of the landscape composition, the total transformed (i.e. non-natural) vegetation area and the proportion cover of different land use categories (natural, urban, cultivated and pine forest plantation) were calculated at two scales; 250 and $500 \mathrm{~m}$ radius buffers in ArcGIS 10.3 (ESRI, Redlands, CA, USA). These radii, while somewhat arbitrary, were selected based on available literature on dispersal distance of beetles and ranges of action of synthetic pheromone traps (Schlyter, 1992; Turchin \& Thoeny, 1993; Turchin \& Odendaal, 1996). The amount of ecotone/transitional area in a $5 \mathrm{~km}$ radius and minimum linear distance to a natural area (often a conservation corridor within a plantation or adjacent conservation land) were also calculated. These variables (32) as well as other climate and/or biogeographic variables (31) (seasonal and annual precipitation, humidity, potential evaporation and latitude, elevation, slope and temperature; table S1) were examined using vector-fitting (function envfit) and generalized additive modeling (GAM, function ordisurf) against the two primary axes of the NMDS results, using R's vegan package (Oksanen et al., 2015). To further examine the correlation between the variables and the beetle communities, we performed model selection, which allows for the comparison of all possible factor combinations as combined predictors (function bioenv in vegan; Oksanen et al., 2015). To reduce computational time and to avoid issues of multicollinearity, we used a subset of the variables in this analysis, selected to minimize cross-correlation among variables and on the best envfit correlations. The community similarity matrix was calculated using Bray-Curtis similarity and the correlations with the environmental matrix using Spearman rank correlation.

\section{Results}

\section{Broad scale patterns of diversity and composition in beetle assemblages}

A total of 4121 beetles belonging to 429 morphospecies and 50 families were identified in this study, of which 299 were identified to genus and 140 to species. (table S2). Of these, 363 morphospecies were collected in at least 2 years and 159 were collected in all 3 years at some subset of sites. Among all families, Scarabaeidae has the highest total richness (77 morphospecies, of which 42 belong to the Melolonthinae), followed by the Curculionidae (57, of which 23 belong to the Scolytinae). Other speciose families included the Carabidae (52 morphospecies), Tenebrionidae (37), Cerambycidae (29), Chrysomelidae (22) and Elateridae (21). 


\section{Exotic beetles in South Africa}

We collected and identified 13 species recognized as exotic to South Africa (table S2). Only the Mediterranean pine engraver, Orthotomicus erosus (Woll.) (Curculionidae: Scolytinae), was common in all sites and areas at least in one of the sampled years, and was by far the most abundant species in the survey, comprising $15 \%$ of all beetles (634 individuals, including 2007) (table 2; fig. S1). Hylastes angustatus (Herbst) (Curculionidae: Scolytinae) was the second most common exotic beetle, only absent from one site (Timbadola, Limpopo), though it was considerably less abundant than 0 . erosus $(2 \pm 2.6$ individuals per sampled location/time point v. $23 \pm 34, t=2.6, \mathrm{df}=15, P=0.02$ ). Hylurgus ligniperda (Fabricius) and Xyleborinus saxesenii (Ratzeburg) were also commonly found in the traps and were present during the 3 years of study. Four nonnative species of the subfamily Scolytinae with no previous records from South Africa were detected in low numbers (table 3). Coccotrypes niger (Eggers), Xyleborus perforans (Woll.), Hypocryphalus robustus (Eichhoff) (syn. mangiferae (Stebbing)) and Hypothenemus birmanus (Eichhoff) (table 3). Pissodes nemorensis Germar (Curculionidae) and Arhopalus syriacus Reitter (Cerambycidae), frequently found associated with Pinus, were captured all 3 years. Pissodes nemorensis was present in all regions, while $A$. syriacus was absent only from the Limpopo province.

Table 2. Beetle abundance, richness and diversity index in pine plantations and dominance of the introduced Orthotomicus erosus in 2008 and 2009.

\begin{tabular}{|c|c|c|c|c|c|c|c|c|c|c|}
\hline \multirow[t]{2}{*}{ Sampling sites } & \multicolumn{2}{|c|}{ Abundance } & \multicolumn{2}{|c|}{$\begin{array}{l}\text { Contribution } \\
\text { to abundance, } \\
\text { O. erosus }\end{array}$} & \multicolumn{3}{|c|}{ Richness } & \multicolumn{3}{|c|}{ Shannon index } \\
\hline & 2008 & 2009 & 2008 & 2009 & 2008 & 2009 & Total & 2008 & 2009 & Total \\
\hline Timbadola, LP & 139 & 239 & $1.44 \%$ & $1.26 \%$ & 75 & 111 & 156 & 4.08 & 4.2 & 4.6 \\
\hline Woodbush, LP & 117 & 69 & $4.27 \%$ & $5.80 \%$ & 35 & 30 & 53 & 2.71 & 3.02 & 3.2 \\
\hline Mariepskop, Forestry, LP & 29 & 84 & $6.90 \%$ & $16.67 \%$ & 19 & 39 & 52 & 2.79 & 3.3 & 3.6 \\
\hline Klipkraal, MP & 81 & 165 & $49.38 \%$ & $0 \%$ & 19 & 50 & 58 & 2.04 & 3.28 & 3.3 \\
\hline Gradely's Farm, MP ${ }^{1}$ & NA & 182 & NA & $4.40 \%$ & NA & 26 & NA & NA & 2.32 & NA \\
\hline Swaziland Plantations, SZ & 281 & 209 & $42.70 \%$ & $36.84 \%$ & 66 & 56 & 92 & 2.77 & 2.97 & 3.0 \\
\hline Dorsbult, MP & 133 & 114 & $6.02 \%$ & $0 \%$ & 41 & 38 & 62 & 3.26 & 2.96 & 3.6 \\
\hline Jessievale, MP & 123 & 166 & $9.76 \%$ & $2.41 \%$ & 42 & 36 & 61 & 3.11 & 2.85 & 3.3 \\
\hline Totals & 1065 & 1735 & $23.8 \%$ & $6.8 \%$ & 211 & 252 & 339 & 4.08 & 4.46 & 4.5 \\
\hline
\end{tabular}

\footnotetext{
${ }^{1}$ Gradely's Farm was only sampled in 2009; while it contributes to the overall abundance, it does not contribute to the overall richness since no unique morphospecies were found in this site.
} 
Table 3. Scolytinae species found in pine plantations, origin and records in South Africa (SA).

\begin{tabular}{|c|c|c|c|}
\hline Species & Origin & Previous records in SA & $\begin{array}{l}\text { No. of } \\
\text { individuals }\end{array}$ \\
\hline Ambrosiodmus natalensis (Schaufuss) & Afrotropical & Yes & 20 \\
\hline Ambrosiodmus obliquus (Leconte) & South America & Yes & 2 \\
\hline Coccotrypes niger (Eggers) & Afrotropical & No & 6 \\
\hline Ctonoxylon uniseriatum (Schedl) & Afrotropical & Yes. Recorded as Ctonoxylon capensis (Schedl) & 1 \\
\hline Cyrtogenius sp. & Unknown & Unknown & 1 \\
\hline Hapalogenius fuscipennis (Chapuis) & Afrotropical & Yes & 1 \\
\hline Hylurgus ligniperda (Fabricius) & Palaearctic & Yes (introduced) & 31 \\
\hline $\begin{array}{l}\text { Hypocryphalus mobustus (Eichhoff) } \\
\text { (Syn. mangiferae Stebbing) }\end{array}$ & Now circumtropical & No (introduced) & 1 \\
\hline Hypothenemus birmanus (Eichhoff) & Now cincumtropical & No (introduced) & 1 \\
\hline Hypothenemus seriatus (Eichhoff) & Now cincumtropical & Yes. Recorded as Stephanoderes vulgaris (Schaufuss) & 1 \\
\hline Hypothenemus sp. 1 & unknown & Unknown & 4 \\
\hline Hypothenemus sp. 2 & unknown & Unknown & 1 \\
\hline Hypothenemus sp. 3 & unknown & Unknown & 1 \\
\hline Hypothenemus sp. 5 & unknown & Unknown & 1 \\
\hline Lanurgus sp. 1 & Afrotropical & Unknown & 4 \\
\hline Lanurgus sp. 2 & Afrotropical & Unknown & 1 \\
\hline Orthotomicus erosus (Wollaston) & $\begin{array}{l}\text { Mediterranean area of Europe, } \\
\text { France, North Africa }\end{array}$ & Yes (introduced) & 634 \\
\hline Xyleborinus aemulus (Wollaston) & Afrotropical & Yes & 2 \\
\hline Xyleborinus saxesenii (Ratzeburg) & Palaearctic & Yes (introduced) & 32 \\
\hline Xyleborus ferrugineus (Fabricius) & Circumtropical & Yes (introduced) & 2 \\
\hline Xyleborus perforans (Wollaston) & Oriental & No (introduced) & 4 \\
\hline
\end{tabular}

\section{Rarefaction-based comparisons of richness and diversity across sites}

The rarefied species richness, diversity and predictions were broadly overlapping for most sites, averaging 63 morphospecies (Shannon Index $=3.3$, Inverse Simpson $=24.8$ ) (figs 2 and S2). One exception was the northernmost (lowest latitude) site, Timbadola, where diversity was clearly higher both years (122 morphospecies, Shannon $=4.6$, Inverse Simpson $=50$ ). Simple regression analyses suggest that latitude and elevation are correlated with richness when data were pooled by year (Pearson's $r=0.73, P=0.036$, Pearson's $r=0.71, P=0.045$ ). These patterns were not significant when analyzed independently by year $(P>0.05)$.
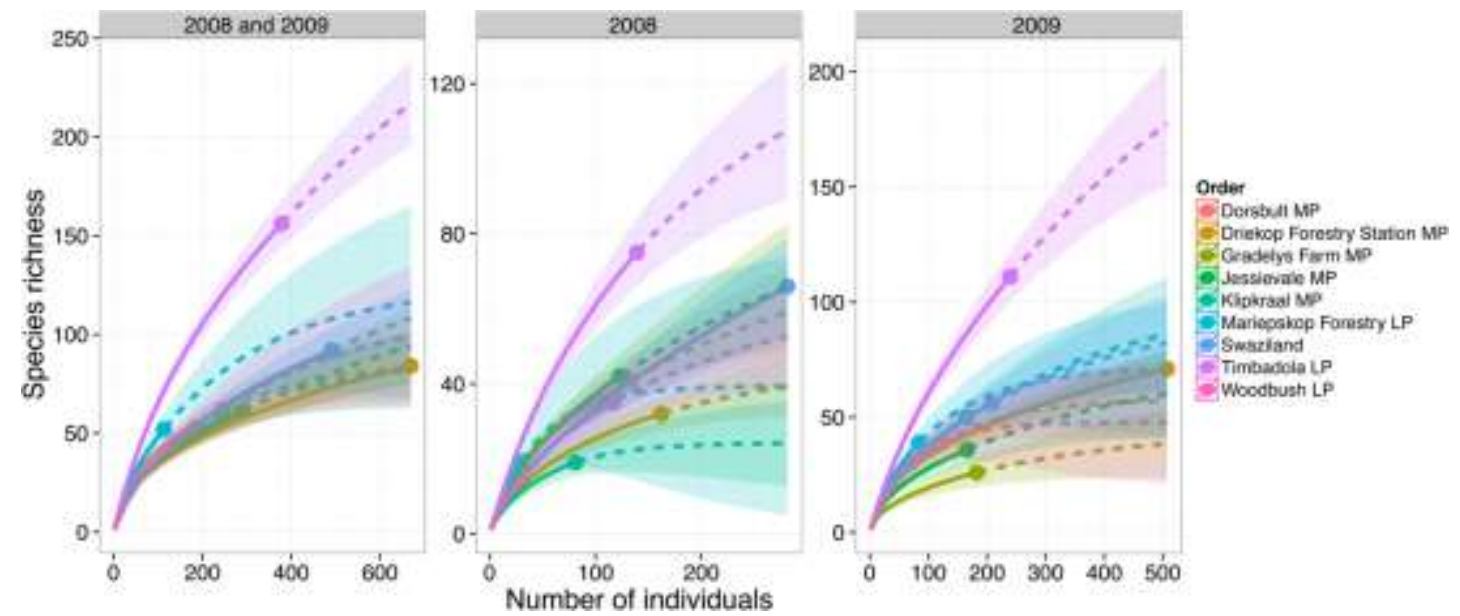

Fig. 2. Individual-based rarefaction and extrapolation of beetle richness from (a) 2008, (b) 2009 and (c) sites pooled across years. 95\% confidence intervals were calculated by a bootstrap method based on 10000 replications. Solid and dashed portions of curves correspond to interpolated and extrapolated richness respectively. 

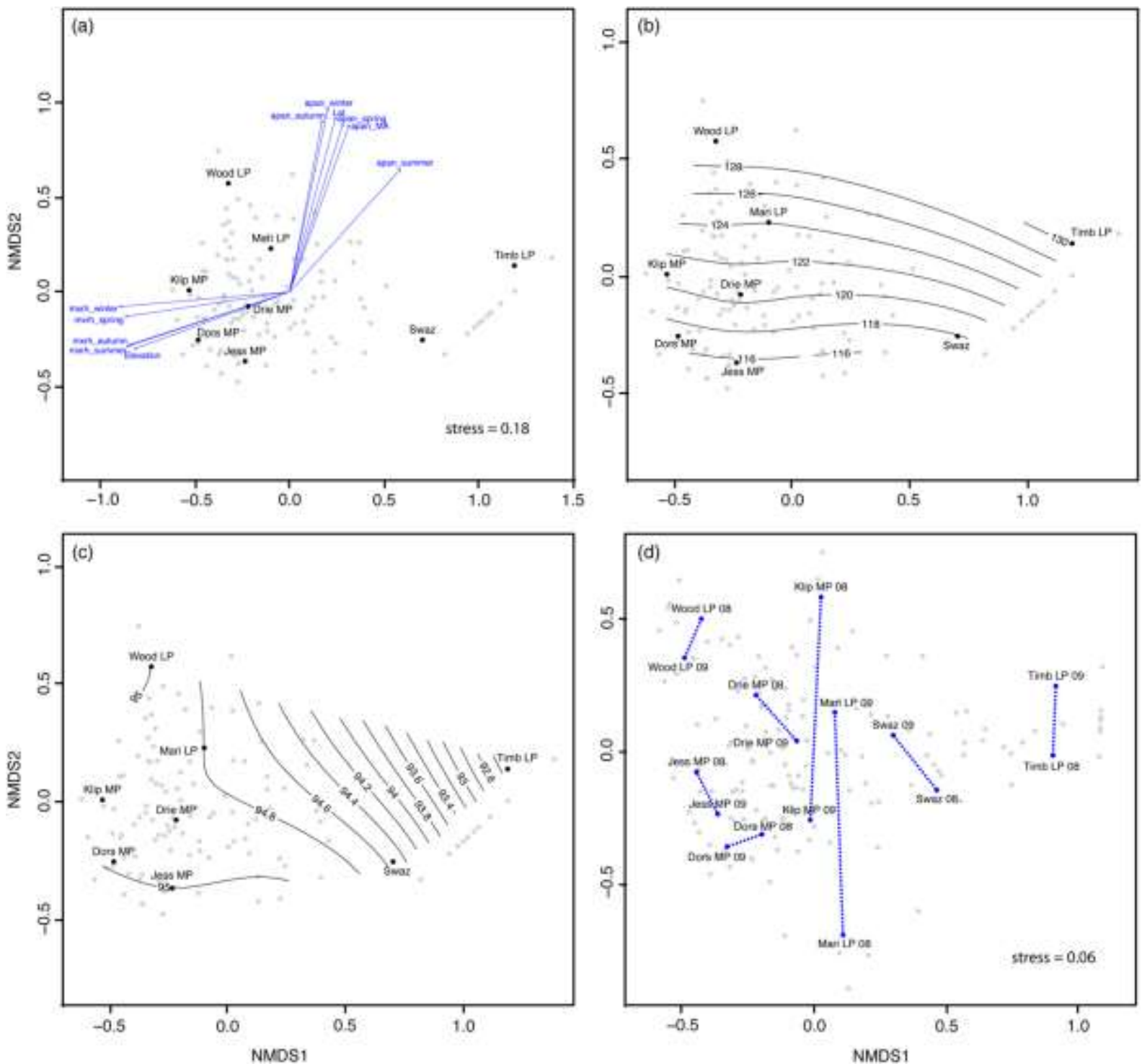

Fig. 3. NMDS of beetle assemblages captured in pine plantations (a) pooled across years (2008-2009) with significant correlations fitted on the ordination (apan = potential evaporation, $\mathrm{mxrh}=$ maximum relative humidity, latitude and elevation) and the General Additive Model (GAM) fitted contours of (b) potential evaporation and (c) maximum relative humidity. (d) Ordination with sites connected (dotted line) across sampling year (2008 and 2009). Grey circles correspond to morphospecies. Data were square root transformed and distance was calculated using Bray-Curtis dissimilarity.

\section{Environmental and landscape-scale predictors of beetle composition}

All seasonal and annual potential evaporation and relative humidity predictors (total $=9$ ), as well as latitude and elevation were significant predictors on community composition (fig. 3a; table S1). The best single predictors of insect community were winter potential evaporation $\left(R^{2}=0.93, P=0.002\right)$ followed by latitude $\left(R^{2}=0.86, P=0.012\right)$ (table S1, fig. 3a and b); however, these variables are highly correlated (fig. S3) and have similar effects. Summer maximum relative humidity $\left(R^{2}=0.76, P=0.007\right)$ was also strongly correlated with community composition (fig. $3 \mathrm{c}$ ). Elevation explained some of the variation in community composition, but was not highly significant $\left(R^{2}=0.72, P=0.05\right)$. None of the temperature variables (15) nor those related to land use (11), distance to natural areas (5) and land 
transformation (2) correlated strongly with beetle composition in the plantation environment $(P>0.05$ for all) - see table S1 for a detailed list of the predictors examined. The best multiple predictor model of community composition contained the combination of three predictors: elevation, potential evaporation in winter and maximum relative humidity in summer (Spearman's $\rho=0.79$ ).

\section{Spatial and temporal stability in beetle assemblages}

In 2008 and 2009, a total of 339 morphospecies were identified; of these 124 were collected both years and the majority (214) were only captured in one of the sites. Overall, 41 morphospecies were collected in the same site across both years. Community composition differed among sites, using years as replicates (PERMANOVA pseudo- $\mathrm{F}=1.70, \mathrm{df}=7,8, R$ ${ }^{2}=0.60, P=0.001$ ) with the Timbadola, Woodbush (Limpopo) and Swaziland (Hhohho Region) communities separating most strongly (figs. 1 and 3). We found evidence for spatial autocorrelation among sites; pairwise similarity in community composition was correlated with distance at a scale of $35 \mathrm{~km}$ (Mantel test: $r=0.39 ; P=0.04$; fig. 4). This correlation was still positive (though non-significant) at $105 \mathrm{~km}$, and dropped to zero by $160 \mathrm{~km}$. There was no effect of sampling year on community composition pooling across sites (pseudo- $\mathrm{F}=0.65$, $\mathrm{df}=1,14 ; P=0.9$; fig. 3d). Overall, abundance, richness and diversity were higher in 2009, though differences were not significant. In general, dominant species were also found across years in similar abundance, with the exception of 0 . erosus, which represented $50 \%$ of beetle abundance in Klipkraal in 2008 and was absent in 2009, when overall beetle diversity was considerably higher.

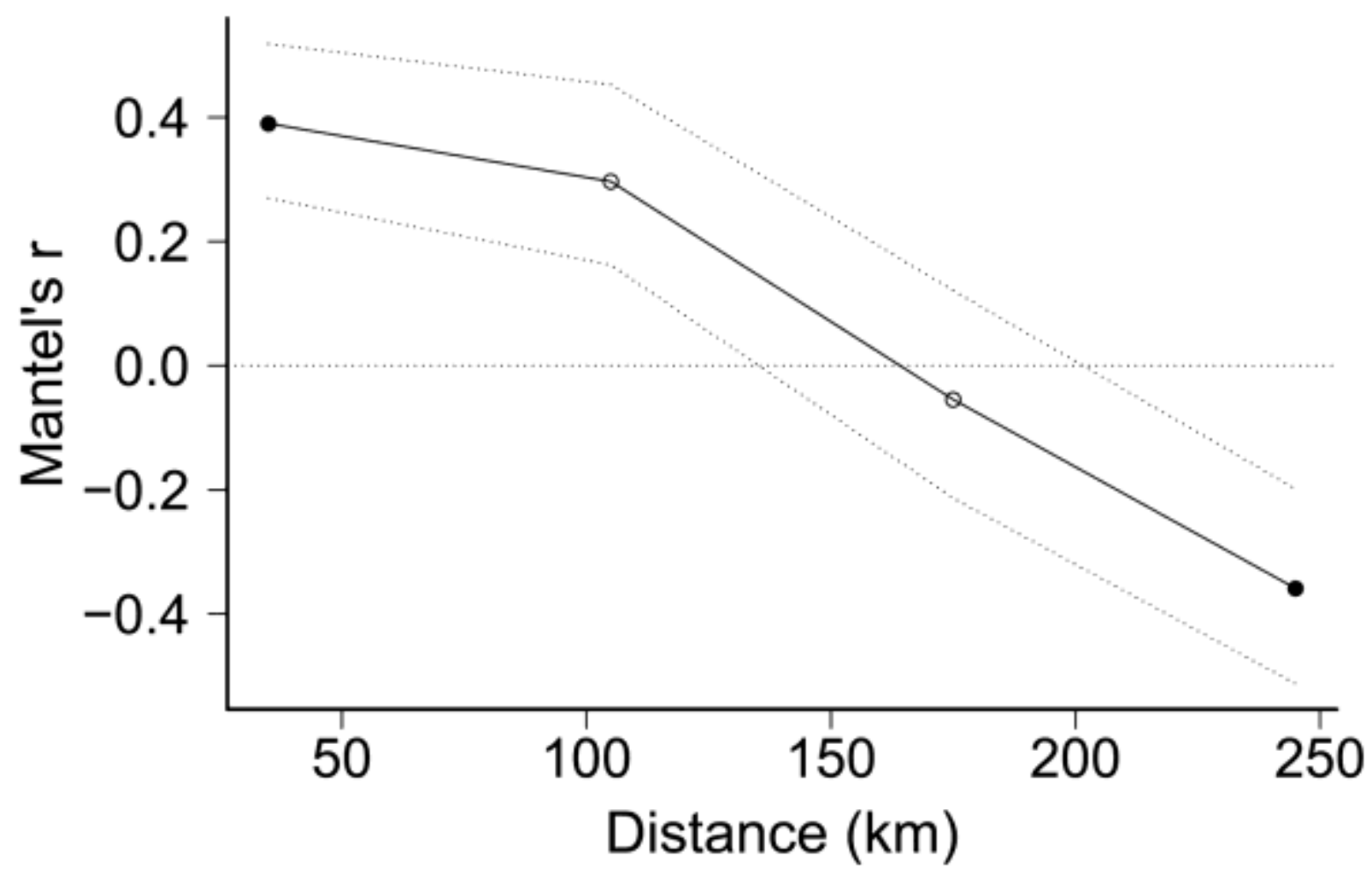

Fig. 4. Mantel correlogram (ecodist R package; Goslee and Urban, 2007) depicting community similarity by distance among sites for beetles captured in kairomone-baited Lindgren funnel traps in South Africa and Swaziland in 2008 and 2009. Filled circles correspond to correlation coefficients that differ significantly from zero at $P<0.05$. Stepping distance was set at $70 \mathrm{~km}$. 


\section{Discussion}

A remarkably large diversity of primarily native beetles was collected as by-catch during the S. noctilio monitoring trials in South Africa between 2007 and 2009 (97\% of species were most likely native). Some of the most speciose and abundant families captured were those that typically include serious plantation pests (i.e. Scarabaeidae, Curculionidae, Cerambycidae). Traps using $\alpha$-pinene lure blends are commonly used to attract a variety of wood-boring insects, particularly on pine (Brockerhoff et al., 2006b ; Miller \& Rabaglia, 2009; Hurley et al., 2015). The lures may show greater attractiveness to introduced, pine feeding insects (no native pines are found in Sub-Saharan Africa) though clearly crossattraction to beetles on native woody or herbaceous hosts occurred, as expected. Phytophagous families not known to contain pest taxa, together with those dominated by predators, fungivores and detritivores were also well represented in the samples. These results align with other studies suggesting plantations can be important habitats for many native (and exotic) insects (Gunther \& New, 2003; Berndt et al., 2008; Pawson et al., 2008; Stone et al., 2010). The degree to which the diversity and abundance of such insects within the plantation environment may influence pest density and damage rates via predation or community level feedbacks is unknown.

As part of our by-catch surveys and analysis, we found four introduced species that were not known to be present in southern Africa prior to this work. While these species are not known to cause damage in pine plantations currently, population behaviour and impacts under exotic conditions can be highly divergent from those in the native range (Keane \& Crawley, 2002). This is especially where potentially virulent microbial associates are involved (Fraedrich et al., 2008; Taerum et al., 2013; Wingfield et al., 2016). Though not all introduced species become invasive (Williamson \& Fitter, 1996) this discovery of four new exotics is highly significant since early detection of potential invaders is critical for effective management or eradication. Hypocryphalus robustus (Eichhoff) (formerly known as Hypocryphalus mangiferae (Stebbing)) is host specific on mango and has been shown to be a vector of the mango sudden decline pathogen Ceratocystis manginecans and is a major pest in Oman, Brazil and Florida (USA) (Yamashiro \& Myazaki, 1985; Al Adawi et al., 2013). This finding could be highly consequential to mango production in southern Africa, though to date no negative impacts have been reported. Neither Coccotrypes nor Hypothenemus is known to be highly aggressive, and while Xyleborus perforans (Woll.) is listed as a high risk invader (CABI, 2016) it is not yet known to attack healthy, live trees (Stone, 1993; Wylie et al., 1999; Brockerhoff et al., 2006a ). Most members of the Coccotrypes and Hypothenemus are seed- or small diameter twig-feeders, but species in these genera (along with Xyleborus) have strong potential to invade due to relative polyphagy (Kalshoven, 1964; Gray, 1968; Wood \& Bright, 1992; Perez-De La Cruz et al., 2009) and the predominance of sib-mating, which could allow establishment via the introduction of only one or a few mated females (Kirkendall, 1983; Haack, 2001; Haack \& Rabaglia, 2013).

The only newly discovered insect known to associate with pine is $X$. perforans, often associated with cut logs and damaged trees (Stone, 1993; Wylie et al., 1999; Brockerhoff et al., 2006a). This species is now invasive in many African countries (UK CAB International, 1973; Wood \& Bright, 1992) so its discovery in South Africa is not surprising. Xyleborus perforans was also one of the most abundant exotic beetles sampled in an S. noctilio by- 
catch survey in Australia (Stone et al., 2010). To date no forest health issues linked to this species have been reported, though the spontaneous acquisition of devastating virulence does have precedence in ambrosia beetles (Hulcr \& Dunn 2011; Wingfield et al., 2016).

\section{Likelihood of unidentified invaders}

The detection of four unknown species given only moderate sampling effort across a vast country and pine resource further suggests that many unknown exotic species may be present in South Africa, and indeed in many undersampled landscapes. We focused on the scolytines as there are known to contain numerous global invaders as well as pests of pine, but also because of the availability of taxonomic expertises in the group. If other groups such as the Cerambycidae or Scarabidae (particularly Melolonthinae) were to be scrutinized at this level, it is quite possible that more introduced species with the potential to cause damage to native or managed ecosystems would be uncovered. In addition to initial detection, maintaining temporally accurate knowledge of introduced species with the potential to impact biodiversity or production is also important for reconstructing invasion pathways (Estoup \& Guillemaud, 2010; Garnas et al., 2016b ; Hurley et al., 2016).

\section{Distribution of beetle invaders in pine-growing regions}

Perhaps unexpectedly in landscapes dominated by exotic pine where numerous invasive insects from their native range have been introduced, the majority of beetles captured in the survey were apparently native. That said, the Mediterranean pine engraver, 0 . erosus, was the most widely captured and numerically dominant species. This could be an artifact of the attractiveness of the kairomone lure to 0 . erosus, but this beetle is known to be invasive in many countries, including South Africa and Swaziland (Tribe \& Kfir, 2001). The wide distribution of this beetle and its apparent high adaptability makes it a potential threat to Pinus species. In South Africa O. erosus commonly occurs together with the exotic bark beetles $H$. ligniperda and $H$. angustatus (Tribe, 1990, 1992). Of these, $H$. angustatus is the most problematic, causing serious damage in pine seedlings (Tribe, 1992). Our results indicate a large dominance of a few introduced invasive scolytine beetles in pine plantations, similar to recent findings in pine-growing regions in Australia (Stone et al., 2010). Some other well-known introduced pests, such as the curculionid $P$. nemorensis, and the cerambycid, $A$. syriacus, were likewise collected in lower abundances than $O$. erosus and with a patchy presence in the samples. $P$. nemorensis is native to North America and has been in South Africa for more than 70 years where it has been reported to cause tip-dieback in some Pinus species, but mostly behaves as an early colonizer on the boles of highly stressed or dying trees (Gebeyehu \& Wingfield, 2003). The limited representation of the weevil in our samples could result from phenological mismatch at the time of sampling, minimal lure attractiveness or could reflect generally low population densities. Both $P$. nemorensis and $A$. syriacus appear to benefit from the invasion of $S$. noctilio, which increases available host tissue (Tribe \& Cillié, 2004); thus populations might be hypothesized to increase in future as wasps establish and spread. However, since S. noctilio wasps were seldom captured in the sample sites examined in this study, it is unlikely that impacts of its presence on these and other beetle populations were strong. 


\section{Spatial variability and temporal stability of beetle communities}

We detected significant biogeographic patterns and temporal stability of beetle assemblages in the 2008-2009 replicated sampling sites. Community stability between years indicates that diversity and composition are determined by local or regional drivers rather than random sampling effects. Klipkraal (Mpumalanga) was one exception, with low beetle diversity in 2008 , which was largely dominated by 0 . erosus individuals. This plantation suffered light fire in 2007 and baboon damage soon after, weakening the trees and likely facilitating the attack by O. erosus in 2008 (Baylis et al., 1986). The reason for the beetle's absence from this site in 2009 is unclear, unless local resources had been depleted. Community composition across sites showed significant differences and our results give an indication of a higher similarity among communities from sites spatially closer to each other. The spatial variation in beetle composition across sites in pine-dominated areas leads to variable exposure to potential colonists and pest threats in each area. Such spatial variability conforms to expectations based on native pest exposure in South Africa where the vast majority of native pests of pines (e.g. Nudaurelia cytherea Fabr., Euproctis terminalis Walker, Colasposoma sp., Hypopholis sommerii Burm) occur sporadically and are typically highly localized, causing damage during high infestations in certain areas while absent or at very low densities at other sites and years (Roux et al., 2012; Garnas et al., 2016a).

\section{Predictors of community composition at local, regional and landscape scale}

A surprisingly large proportion of the variation in community composition was explained by a small number of highly correlated variables, namely latitude, maximum relative humidity and potential evaporation. Although elevation was only moderately correlated to community composition, when analyzed independently, this variable was included in the preferred multi-variable model. Temperature and landscape composition variables, originally hypothesized to be relevant, were not found to have explanatory power either alone or in combination. The absence of an effect of proximity to natural or conservation areas indicates that diverse insects either occur inside plantations (whether within pine compartments or in conservation corridors, which traverse plantations) or are attracted from adjacent habitats. This mirror results from a recent study in Australia that show that beetle assemblages did not significantly differ within pine plantations vs. adjacent native vegetation (Stone et al., 2010).

\section{Non-phytophagous morphospecies}

Non-phytophagous insects were also abundant in our samples. Carabid ground beetles were the second most speciose family in the study and were also abundant in traps. The presence of carabids in plantations may be beneficial as they are typically predaceous and are known to feed on a wide range of damaging insects in agriculture such as aphids, caterpillars and dipterans (Kromp, 1999). They are also frequently used as biodiversity indicators due to their apparent sensitivity to environmental change (Gunther \& New, 2003; Berndt et al., 2008). Their high diversity and abundance in plantation forests suggests that these humanmodified habitats can be used by native species as alternative habitats in fragmented areas (Pawson et al., 2008). Darkling beetles (Tenebrionidae) were also numerous, most likely reflecting the large diversity of this group in South Africa. While there are limited studies on 
this group they might also be good ecological indicators (Chen et al., 2006; Fattorini, 2010). Finally, Zopheridae, Passandridae, Salpingidae, Histeridae, Nitidulidae and Laemophloeidae were minimally diverse in our samples ( 27 morphospecies in total) but some morphospecies were well represented. Most of these families have been poorly studied but include some species that can be beneficial predators or ectoparasites of wood-boring insects (Thomas, 2002; Shepherd et al., 2005; Lord et al., 2011).

\section{Limitations and recommendations for future by-catch-based studies}

By-catch data by definition represents an ad hoc information emerging from sampling performed for a distinct, often highly applied purpose. While such data can be highly informative for the reasons stated above, it is important to consider key limitations as well as known or potential sources of bias. In the current case, we only sampled within Pinus plantations and employed a kairomone lure that - while designed to mimic stressed pine volatiles - is of unknown specificity or attractiveness across a diverse native and exotic beetle assemblage. In fact, volatiles containing $\alpha$-pinene can be a deterrent to some insects, particularly broadleaf-feeding beetles in North America (Kelsey \& Joseph 1997). The dominance by native insects clearly indicates that the species pool from which our samples were drawn is considerably broader than exotic pine-feeding or pine-associated insects, a habitat, which cited as depauperate (Prinsloo \& Uys, 2014), though may suggest that pinedominated ecosystems are more diverse than previously thought. Sampling did seem to be fairly effective at capturing known pine-feeding insects, though relative effectiveness across species or groups is not clear. While the use of morphospecies as surrogates for taxonomic species-level identification is suitable to study general patterns of diversity and composition (e.g., with respect to environmental gradients or landscape feature), we recognize it limits certain aspects of our study such as the detection of potential risk species.

Finally, the question remains of how S. noctilio itself influences the diversity and structure of communities. While community impacts seem likely and have been shown in other systems (Ryan et al., 2012), the early-detection focus of the trapping in this study does not allow us to address this specifically. Future studies that directly compare results with our dataset, or specifically sample across a gradient of $S$. noctilio densities or time since infestation in a landscape context, would be valuable.

Our results add to our knowledge of exotic and indigenous fauna, their distribution and seasonal occurrence and represent a snapshot of the pool of possible colonists that co-occur or are linked with the pine resource. Furthermore, these data have the potential to advance our understanding of how introduced insect species may alter patterns of species occurrence and abundance. While analyzing by-catch data can be challenging, this kind of studies can contribute to address ecological questions as well as in the identification of threats to agriculture and conservation and provide insight into general ecosystem health.

\section{Acknowledgements}

We would like to thank Roger A. Beaver, Riaan Stals and Elizabeth Grobbelaar (Plant Protection Research Institute, Agricultural Research Council, South Africa) and Ruth Muller (Ditsong Museum, South Africa) for the assistance provided in the identification of 
specimens and Elmé Braytenbach and Khanyisa Vundle for the help provided in processing the samples. We also thank Ilaria Germishuizen (Institute for Commercial Forestry Research, South Africa) for her comments and assistance with the data analyses and Philip Croft (National Sirex Coordinator, ICFR) for providing us with the by-catch material. This project was funded by the DST-NRF Centre of Excellence in Tree Health Biotechnology and the Tree Protection Cooperative Programme.

\section{References}

Al Adawi, A.O., Al Jabri, R.M., Deadman, M.L., Barnes, I., Wingfield, B. \& Wingfield, M.J. (2013) The mango sudden decline pathogen, Ceratocystis manginecans, is vectored by Hypocryphalus mangiferae (Coleoptera: Scolytinae) in Oman. European Journal of Plant Pathology 135, 243-251.

Aukema, J.E., McCullough, D.G., Von Holle, B., Liebhold, A.M., Britton, K. \& Frankel, S.J. (2010) Historical accumulation of nonindigenous forest pests in the continental United States. BioScience 60, 886-897.

Babin-Fenske, J., Anand, M. \& Alarie, Y. (2008) Rapid morphological change in stream beetle museum specimens correlates with climate change. Ecological Entomology 33, 646-651.

Baylis, N.T., De Ronde, C. \& James, D.B. (1986) Observations of damage of a secondary nature following a wild fire at the Otterford State Forest. South African Forestry Journal 137, $36-37$.

Berndt, L.A., Brockerhoff, E.G. \& Jactel, H. (2008) Relevance of exotic pine plantations as a surrogate habitat for ground beetles (Carabidae) where native forest is rare. Biodiversity and Conservation 17, 1171-1185.

Brockerhoff, E.G., Bain, J., Kimberley, M. \& Knižek, M. (2006 a) Interception frequency of exotic bark and ambrosia beetles (Coleoptera: Scolytinae) and relationship with establishment in New Zealand and worldwide. Canadian Journal of Forest Research 36, 289298.

Brockerhoff, E.G., Jones, D.C., Kimberley, M.O., Suckling, D.M. \& Donaldson, T. (2006 b) Nationwide survey for invasive wood-boring and bark beetles (Coleoptera) using traps baited with pheromones and kairomones. Forest Ecology and Management 228, 234-240.

Buchholz, S., Kreuels, M., Kronshage, A., Terlutter, H. \& Finch, O.D. (2011) Bycatches of ecological field studies: bothersome or valuable? Methods in Ecology and Evolution 2, 99102.

CABI (2016) Invasive Species Compendium. Wallingford, UK, CAB International. Available online at http://www.cabi.org/isc

Chao, N., Gotelli, N.J., Hsieh, T.C., Sander, E.L., Ma, K.H., Colwell, R.K. \& Ellison, A.M. 
(2014) Rarefaction and extrapolation with Hill numbers: a framework for sampling and estimation in species diversity studies. Ecological Monographs 84, 45-67.

Chen, Z., Grady, K., Stephens, S., Villa-Castillo, J. \& Wagner, M.R. (2006) Fuel reduction treatment and wildfire influence on carabid and tenebrionid community assemblages in the ponderosa pine forest of northern Arizona, USA. Forest Ecology and Management 225, 168177.

Crook, D.J., Francese, J.A., Rietz, M.L., Lance, D.R., Hull-Sanders, H.M., Mastro, V.C., Silk, P. J. \& Ryall, K.L. (2014) Improving detection tools for emerald ash borer (Coleoptera:

Buprestidae): comparison of multifunnel traps, prism traps, and lure types at varying population densities. Journal of Economic Entomology 107, 1496-1501.

DiGirolomo, M.F. \& Dodds, K.J. (2014) Cerambycidae bycatch from Asian longhorned beetle survey traps placed in forested environs. Northeastern Naturalist 21, N28-N34.

Estoup, A. \& Guillemaud, T. (2010) Reconstructing routes of invasion using genetic data: why, how and so what? Molecular Ecology 19, 4113-4130.

Etxebeste, I., Lencina, J.L. \& Pajares, J. (2013) Saproxylic community, guild and species responses to varying pheromone components of a pine bark beetle. Bulletin of Entomological Research 103, 497-510.

Fattorini, S. (2010) Effects of fire on tenebrionid communities of a Pinus pinea plantation: a case study in a Mediterranean site. Biodiversity and Conservation 19, 1237-1250.

Fraedrich, S.W., Harrington, T.C., Rabaglia, R.J., Ulyshen, M.D., Mayfield, A.E. III, Hanula, J.L., Eickwort, J.M. \& Miller, D. R. (2008) A fungal symbiont of the redbay ambrosia beetle causes a lethal wilt in redbay and other Lauraceae in the southeastern United States. Plant Disease 92, 215-224.

Garnas, J., Roux, J., Hurley, B., Slippers, B., Wingfield, M.J. (2016 a) Insects and diseases of Mediterranean forests: A South African perspective. pp. 397-430 in T.D. Paine \& F. Lieutier (Eds) Insects and Diseases of Mediterranean Forest Systems. Switzerland, Springer International Publishing.

Garnas, J., Auger-Rozenberg, M. \& Roques, A., Bertelsmeier, C., Wingfield, M.J., Saccaggi, D.L., Roy, H.E. \& Slippers, B. (2016 b) Complex patterns of global spread in invasive insects: eco-evolutionary and management consequences. Biological Invasions 18, 935-952.

Gebeyehu, S. \& Wingfield, M.J. (2003) Pine weevil Pissodes nemorensis: threat to South African pine plantations and options for control: review article. South African Journal of Science 99, 531.

Gray, B. (1968) Forest tree and timber insect pests in the Territory of Papua and New Guinea. Pacific Insects 10, 301-323. 
Goslee, S.C. \& Urban, D.L. (2007) The ecodist package for dissimilarity-based analysis of ecological data. Journal of Statistical Software 22, 1-19.

Gotelli, N.J. \& Colwell, R.K. (2011) Estimating species richness. pp. 39-54 in A.E. Magurran \& B.J. McGill (Eds) Biological Diversity: Frontiers in Measuring Biodiversity. New York, Oxford University Press.

Gotelli, N.J. \& Colwell, R.K. (2003) Exotic pine plantations in Victoria, Australia: a threat to epigaeic beetle (Coleoptera) assemblages? Journal of Insect Conservation 7, 73-84.

Haack, R.A. (2001) Intercepted Scolytidae (Coleoptera) at US ports of entry: 1985-2000. Integrated Pest Management Reviews 6, 253-282.

Haack, R.A. \& Rabaglia, R.J. (2013) Exotic bark and ambrosia beetles in the USA: potential and current invaders. pp. 48-74 in J. Peña (Ed.) Potential Invasive Pests of Agricultural Crops. Boston, MA, CAB International.

Hatten, T.D., Looney, C., Strange, J.P. \& Bosque-Pérez, N.A. (2013) Bumble bee fauna of Palouse Prairie: survey of native bee pollinators in a fragmented ecosystem. Journal of Insect Science 13, 1-19.

Hsieh, T.C., Ma, K.H. \& Chao, A. (2014) iNEXT: iNterpolation and EXTrapolation for species diversity. $R$ package version 2.0. Available online at http://chao.stat.nthu.edu.tw/blog/software-download

Hulcr, J., and Dunn, R.R. (2011) The sudden emergence of pathogenicity in insect-fungus symbioses threatens naive forest ecosystems. Proceedings of the Royal Society B: Biological Sciences 278, 2866-2873.

Hurley, B.P., Slippers, B. \& Wingfield, M.J. (2007) A comparison of control results for the alien invasive woodwasp, Sirex noctilio, in the Southern Hemisphere. Agricultural and Forest Entomology 9, 159-171.

Hurley, B.P., Croft, P., Verleur, M., Wingfield, M.J. \& Slippers, B. (2012) The control of the Sirex woodwasp in diverse environments: the South African experience. pp. 247-264 in B. Slippers , P. de Groot \& M.J. Wingfield ( $E d s)$ The Sirex Woodwasp and its Fungal Symbiont: Research and Management of a Worldwide Invasive Pest. Netherlands, Springer.

Hurley, B.P., Garnas, J. \& Cooperb, M.F. (2015) Assessing trap and lure effectiveness for the monitoring of Sirex noctilio. Agricultural and Forest Entomology 17, 64-70.

Hurley, B.P., Garnas, J., Wingfield, M.J., Branco, M., Richardson, D.M., Slippers, B. (2016) Increasing numbers and intercontinental spread of invasive insects on eucalypts. Biological Invasions 18, 921-933.

Jactel, H., Brockerhoff, E. \& Duelli, P. (2005) A test of the biodiversity-stability theory: metaanalysis of tree species diversity effects on insect pest infestations, and re-examination of 
responsible factors. pp. 235-262 in M. Scherer-Lorenzen , C. Körner \& E.D. Schulze (Eds) Forest Diversity and Function, Berlin Heidelberg, Springer.

Kalshoven, L.G.E. (1964) The occurrence of Xyleborus perforans (Woll.) and X. similis in Java (Coleoptera, Scolytidae). Beaufortia 11, 131-142.

Keane, R.M. \& Crawley, M.J. (2002) Exotic plant invasions and the enemy release hypothesis. Trends in Ecology \& Evolution 17, 164-170.

Kelsey, R.G. \& Joseph, G. (1997) Ambrosia beetle host selection among logs of douglas fir, western hemlock, and western red cedar with different ethanol and $\alpha$-pinene concentrations. Journal of Chemical Ecology 23, 1035-1051.

Kirkendall, L.R. (1983) The evolution of mating systems in bark and ambrosia beetles (Coleoptera: Scolytidae and Platypodidae). Zoological Journal of the Linnean Society 77, 293-352.

Kromp, B. (1999) Carabid beetles in sustainable agriculture: a review on pest control efficacy, cultivation impacts and enhancement. Agriculture, Ecosystems \& Environment 74, 187-228.

Lantschner, M.V., Villacide, J.M., Garnas, J.R., Croft, P., Carnegie, A.J., Liebhold, A.M. \& Corley, J.C. (2014) Temperature explains variable spread rates of the invasive woodwasp Sirex noctilio in the Southern Hemisphere. Biological Invasions 16, 329-339.

Lord, N.P., Nearns, E.H. \& Miller, K.B (2011) Ironclad ID: Tool for Diagnosing Ironclad and Cylindrical Bark Beetles (Coleoptera: Zopheridae) of North America North of Mexico. USA, The University of New Mexico and Center for Plant Health Science and Technology, USDA, APHIS, PPQ. Available at: http://coleopterasystematics.com/ironcladid/index.html

Maleque, M.A., Maeto, K. \& Ishii, H.T. (2009) Arthropods as bioindicators of sustainable forest management, with a focus on plantation forests. Applied Entomology and Zoology 44, $1-11$.

Martin, A., Etxebeste, I., Pérez, G., Álvarez, G., Sánchez, E. \& Pajares, J. (2013) Modified pheromone traps help reduce bycatch of bark-beetle natural enemies. Agricultural and Forest Entomology 15, 86-97.

Miller, D.R. \& Rabaglia, R.J. (2009) Ethanol and (-)- $\alpha$-pinene: Attractant kairomones for bark and ambrosia beetles in the southeastern US. Journal of Chemical Ecology 35, 435-448.

Oksanen, J., Blanchet, G.F., Kindt, R., Legendre, P., Minchin, P. R., O’Hara, R.B., Simpson, G.L., Solymos, P., Stevens, M.H. H. \& Wagner, H. (2015) vegan: Community Ecology Package. $\mathrm{R}$ package version 2.3-0. Available online at http://CRAN.R-project.org/package=vegan 
Pawson, S.M., Brockerhoff, E.G., Meenken, E.D. \& Didham, R.K. (2008) Non-native plantation forests as alternative habitat for native forest beetles in a heavily modified landscape. Biodiversity and Conservation 17, 1127-1148.

Perez-De La Cruz, M., Equihua-Martinez, A., Romero-Napoles, J., Sanchez-Soto, S. \& GarciaLopez, E. (2009) Diversity, dynamic population and host plants of bark and ambrosia beetles (Coleoptera: Curculionidae) associated to the cocoa agroecosystem in Tabasco, Mexico. Revista Mexicana de Biodiversidad 80, 779-791.

Prinsloo, G. \& Uys, V. (Eds.) (2014) Insects of Cultivated Plants and Natural Pastures in Southern Africa. Pretoria, Entomological Society of Southern Africa.

R Core Team (2015) R: A Language and Environment for Statistical Computing. Vienna, Austria, R Foundation for Statistical Computing. Available online at http://www.Rproject.org/

Roux, J., Hurley, B.P. \& Wingfield, M.J. ( (2012) Diseases and pests of eucalypts, pines and wattle. pp. 303-336 in B.V. Bredenkamp \& S.J. Upfold (Eds) South African Forestry Handbook. 5th edn. South Africa, South African Institute for Forestry.

Ryan, K., de Groot, P. \& Smith, S.M. (2012) Evidence of interaction between Sirex noctilio and other species inhabiting the bole of Pinus . Agricultural and Forest Entomology 14, 187195.

Schlyter, F. (1992) Sampling range, attraction range, and effective attraction radius: estimates of trap efficiency and communication distance in coleopteran pheromone and host attractant systems. Journal of Applied Entomology 114, 439-454.

Scholtz, C.H. \& Holm, E. (2012) Insects of Southern Africa. 2nd edn. Pretoria, South Africa, Butterworths.

Shepherd, W.P., Sullivan, B.T., Goyer, R.A. \& Klepzig, K.D. (2005) Electrophysiological and olfactometer responses of two histerid predators to three pine bark beetle pheromones. Journal of Chemical Ecology 31, 1101-1110.

Skvarla, M.J. \& Holland, J.D. (2011) Nontarget insects caught on emerald ash borer purple monitoring traps in western Pennsylvania. Northern Journal of Applied Forestry 28, 219221.

Slippers, B., Hurley, B.P., Wingfield, M.J. (2015) Sirex woodwasp: a model for evolving management paradigms of invasive forest pests. Annual Review of Entomology 60, 601-619.

Spears, L.R. \& Ramirez, R.A. (2015) Learning to love leftovers. American Entomologist 61, 168-173. 
Stone, C. (1993) Survey of arthropods from billets of Pinus following infestation by Ips grandicollis (Eichhoff) Coleoptera: Scolytidae) in Northeaster New South Wales. Australian Journal of Entomology 32, 289-296.

Stone, C., Goodyer, G., Sims, K., Penman, T. and Carnegie, A. (2010) Beetle assemblages captured using static panel traps within New South Wales pine plantations. Australian Journal of Entomology 49, 304-316.

Taerum, S.J., Duong, T.A., De Beer, Z.W., Gillette, N., Sun, J.H., Owen, D.R. \& Wingfield, M.J. (2013) Large shift in symbiont assemblage in the invasive red turpentine beetle. PLoS ONE 8, e78126.

Thomas, D.B. (2003) Nontarget insects captured in fruit fly (Diptera: Tephritidae) surveillance traps. Journal of Economic Entomology 96, 1732-1737.

Thomas, M.C. (2002) Family 81. Passandridae Erichson 1845. pp. 327-328 in Arnett, R.H. Jr., Thomas, M.C., Skelley, P.E. and Frank, J.H (Eds) American Beetles, Volume 2. Polyphaga: Scarabaeoidea through Curculionoidea. Boca Raton, CRC Press.

Tribe, G.D (1990) Phenology of Pinus radiata log colonization and reproduction by the European bark beetle Orthotomicus erosus (Wollaston)(Coleoptera: Scolytidae) in the southwestern Cape Province. Journal of the Entomological Society of Southern Africa 53, 117126.

Tribe, G.D (1992) Colonisation sites on Pinus radiata logs of the bark beetles, Orthotomicus erosus, Hylastes angustatus and Hylurgus ligniperda (Coleoptera: Scolytidae). Journal of the Entomological Society of Southern Africa 55, 77-84.

Tribe, G.D (1995) The woodwasp Sirex noctilio Fabricius (Hymenoptera: Siricidae), a pest of Pinus species, now established in South Africa. African Entomology, 3, 215-217.

Tribe, G.D. \& Cillié, J.J. (2004) The spread of Sirex noctilio Fabricius (Hymenoptera: Siricidae) in South African pine plantations and the introduction and establishment of its biological control agents. African Entomology 12, 9.

Tribe, G.D. \& Kfir, R. ( 2001) The establishment of Dendrosoter caenopachoides (Hymenoptera: Braconidae) introduced into South Africa for the biological control of Orthotomicus erosus (Coleoptera: Scolytidae), with additional notes on D. sp. nr. labdacus . African Entomology 9, 195-198.

Turchin, P. \& Odendaal, F.J. (1996) Measuring the effective sampling area of a pheromone trap for monitoring population density of southern pine beetle (Coleoptera: Scolytidae). Environmental Entomology 25, 582-588.

Turchin, P. \& Thoeny, W.T. (1993) Quantifying dispersal of southern pine beetles with markrecapture experiments and a diffusion model. Ecological Applications 3, 187-198. 
UK CAB International (1973) Xyleborus Perforans. [Distribution map]. Distribution Maps of Plant Pests, December. Wallingford, UK, CAB International, Map 320.

Vandermeer, J., van Noordwijk, M., Anderson, J., Ong, C. \& Perfecto, I. (1998) Global change and multi-species agroecosystems: concepts and issues. Agriculture, Ecosystems \& Environment 67, 1-22.

Vergara, C.H. \& Badano, E.I. (2009) Pollinator diversity increases fruit production in Mexican coffee plantations: the importance of rustic management systems. Agriculture, Ecosystems \& Environment 129, 117-123.

Williamson, M. \& Fitter, A. (1996) The varying success of invaders. Ecology 77, 1661-1666.

Wingfield, M.J., Garnas, J., Hajek, A., Hurley, B.P., De Beer, Z. W. \& Taerum, S.J. (2016) Novel and co-evolved associations between insects and microorganisms as drivers of forest pestilence. Biological Invasions 18, 1045-1056.

Wood, S.L. \& Bright, D.E. (1992) A catalog of Scolytidae and Platypodidae (Coleoptera), part 2: taxonomic index volume A. Great Basin Naturalist Memoirs 13, 1-833.

Wylie, F.R., Peters, B., DeBaar, M., King, J. \& Fitzgerald, C. () Managing attack by bark and ambrosia beetles (Coleoptera: Scolytidae) in fire-damaged Pinus plantations and salvaged logs in Queensland, Australia. Australian Forestry 62, 148-153.

Yamashiro, T. \& Myazaki, I. (1985) Principal pests and diseases of mango-Mangifera indica L.-in the State of São Paulo and updated control methods. Biológico 51, 41-50. 